\title{
Climate, copepods and cod: some thoughts on the long-range prospects for a sustainable northern cod fishery
}

\author{
Robert J. Conover, Scott Wilson, Gareth C. H. Harding, W. Peter Vass
}

Fisheries and Oceans, Bedford Institute of Oceanography, PO Box 1006, Dartmouth, Nova Scotia, Canada B2Y 4A2

\begin{abstract}
Cod Gadus morhua stocks on the Labrador Shelf and Grand Banks, NW Atlantic, are apparently at an all-time low. While overfishing has undoubtedly occurred, it is probable that other factors are affecting stock recruitment as well. Water temperatures and salinity are also unusually low, which may have affected the abundance of cod in some way. Northern cod begin spawning in March in most stock management zones around Newfoundland, Canada. First-feeding cod larvae survive in waters less than $2^{\circ} \mathrm{C}$ but require suitable prey, especially nauplii of the copepod Calanus finmarchicus, to grow well. The 'match/mismatch' hypothesis assumes that cod spawn at the same time each year, but spawning by copepods may or may not 'match' depending on the stimulus provided by the 'spring bloom' of phytoplankton, which can vary with environmental conditions by up to $6 \mathrm{wk}$. While C. finmarchicus is common in the Atlantic waters of the Labrador Sea and Grand Banks, zooplankton in the Labrador Current, especially during this period of low temperature and salinity, are dominated by 2 arctic copepods, C. glacialis and C. hyperboreus, which have different spawning seasons, and therefore probably would not provide a good nutritional match for young cod. Despite global warming, sea water supporting important demersal fish on the continental shelf off northeast Canada is presently colder and fresher than normal. Global warming may have induced melting of glaciers and sea ice and increased runoff in rivers entering the Arctic Ocean and its coastal drainage, reducing salinity at the sea surface, increasing stability and reducing deep convection, and hence upward heat transport. Several cold, fresh 'anomalies' have been observed in the last few decades and they have contributed to less favourable conditions at locations around the North Atlantic. These anomalies may be part of an interdecadal climate cycle of alternating warm and cold periods, the effects of which must be removed to clearly identify those associated with global warming. Whatever the causes, periods of 'ocean cooling', with potentially serious consequences for the cod fishery, may be predictable. Increasing amounts of ice in the eastern Arctic and Greenland Sea are easily monitored by satellite and appear to anticipate reduced temperature/salinity anomalies in the Labrador Sea by about 4 yr. Climatic impacts, whether cyclic or continuing, could be identified sufficiently far in advance to enable modifications in management of the fishery toward at least mollifying their effects, thus improving the prospects for long-term sustainability.
\end{abstract}

KEY WORDS: Recruitment - Calanus · Copepod nauplii - Cod Gadus morhua First feeding · Spring bloom $\cdot$ Sea surface temperature $\cdot$ Salinity anomaly $\cdot$ Banks $\cdot$ Currents $\cdot$ Polar front

\section{INTRODUCTION}

The relationship between commercial fish species and their physical environment has long been of interest to fisheries scientists. With the increasing awareness that human activity has altered the global atmosphere through the production or anthropogenic release of so-called greenhouse gasses and the correl- ative evidence that the mean global temperature has increased over the last century, we should anticipate that the environment of fish will be subject to shortand long-term, climatically related variability in our attempts to forecast harvestable stocks. At this time the cod Gadus morhua stocks on the Newfoundland banks are apparently at an all-time low (Anonymous 1994; Fig. 1). There is evidence that the management tactics 


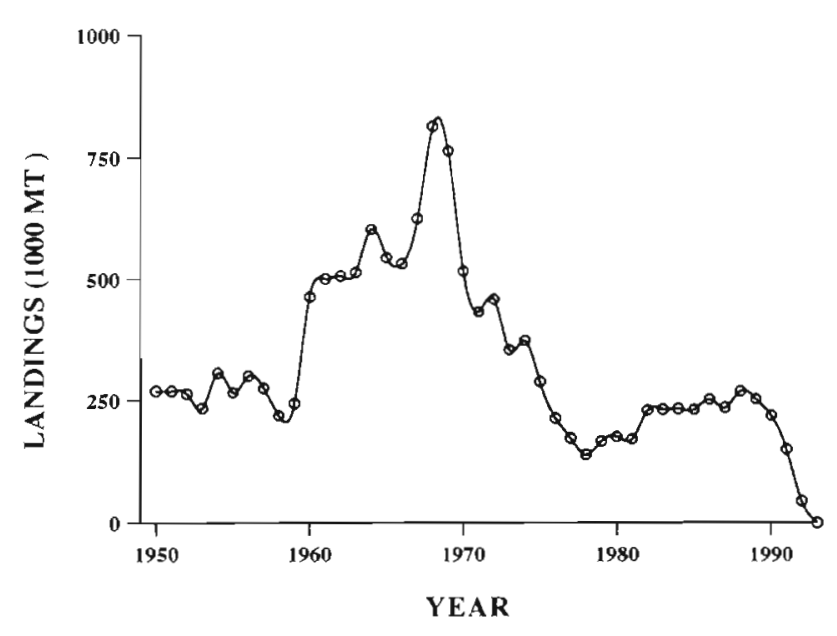

Fig. 1. Northern cod Gadus morkua landings in NAFO management areas $2 \mathrm{~J} 3 \mathrm{~K}$ and $3 \mathrm{~L}$ between 1950 and 1992. A moratorium on the taking of groundfish in these areas was imposed in June 1992

recently applied to maritime groundfish stocks did not control fishing effort at target levels of mortality, so that prior to closure of the northern cod fishery in June 1992, there were insufficient reproducing adults to sustain the population (Sinclair pers. comm.). These tactics were partially responsible for the collapse of the fishery, but they are probably only part of the problem.

Identifying the cause (or causes) of such a collapse is difficult, but, aside from overfishing, recruitment failure, from whatever cause, is a common explanation. In addition to poor feeding conditions for young fish or predation, some physical forcing mechanism such as strong winds, perhaps from an unfavourable direction, or temperatures too cold and/or salinity too low may be responsible. Here it is relevant to mention that temperatures in the environment of the northern cod near the Labrador coast and on the northern Grand Banks off Newfoundland have been unusually cold, with positive ice anomalies, in recent years and the salinity unusually low (Myers et al. 1993b, Prinsenberg et al. 1993).

The main thrust of this paper is the response of certain marine organisms and/or communities to changes, whatever their probable cause, in arctic climate. The collapse of the northern cod fishery has generated a considerable and wide-ranging research effort in Maritime Canada in fisheries biology, physical oceanography and climate-related research. Here we attempt to synthesize recent developments in each of these disciplines as they may be affecting northern cod stocks, and we suggest 2 areas for further research that we believe may have short- and possibly long-term potential for monitoring the state of, and perhaps forecasting future trends in, the fishery.

\section{RECRUITMENT AND THE RESPONSE OF NORTH- ERN COD TO THE CHANGING ENVIRONMENT}

\section{Historical background and the critical period}

We will not go into the ecology of northern cod in great detail except to review some of the thinking about its recruitment and how a variable climate may affect it. There have been a number of attempts to evaluate cause and effect where recruiting success or failure has been clearly established. While the explanations differ considerably, the major source of variability in year-class strength probably occurs during the larval or very early juvenile stages (Myers and Cadigan 1993). It follows then that the period of early development in many fish larvae is 'critical' to predicting recruitment, which was recognized early in this century (Hjort 1914).

In his original formulation, Hjort defined the critical period as the time between the hatching of the yolksac-bearing larva and 'first feeding'. In northern cod at $3^{\circ} \mathrm{C}$, feeding can be initiated as early as $5 \mathrm{~d}$ after hatching but must be initiated by 10 to $20 \mathrm{~d}$ after hatching, or the larva reaches the 'point of no return' and starves to death (Ellertsen et al. 1980). In the case of cod the period of spawning is quite conservative and does not vary greatly with temperature (Ellertsen et al. 1989). However, the timing of the spring bloom of phytoplankton is quite variable, being influenced by temperature, salinity, light intensity, wind speed and direction, as they affect stability of the water column, and doubtless other intangibles (Sverdrup 1953). This concept of year-class regulation is known as the 'match/mismatch' hypothesis, although the critical period has been extended to include all of larval life at least to metamorphosis when the young cod becomes a free-swimming juvenile (Cushing 1974, 1990).

The so-called spring bloom of phytoplankton in most north temperate and arctic locations consists primarily of relatively large diatoms. While first-feeding larvae of cod can ingest diatoms and other plant plankton, they do not grow well on smaller flagellates, which Ellertsen et al. (1980) believed were ingested by 'accident'. More recent studies by Van der Meeren (1991) demonstrate that the smaller phytoplankton are taken by filter-feeding and in proportion to their concentration. In a mesocosm, he found that filter-feeding on 'natural' phytoplankton occurred as part of the transformation from non-feeding to a particle-feeding larva with a functional jaw, a process that took place gradually over several days. This transformation process has been investigated in greater detail in a recent comparative study of the early life history of 'northern' (North Atlantic Fisheries Organisation Divisions 2J3KL) and 'southern' (Nova Scotian) Maritime cod stocks (Hunt von Herbing 1994). 
However, in addition to affording 'first-feeding' nutrition to larval cod, phytoplankton is a stimulus for reproduction by zooplankton, primarily copepods, and it is the eggs and early developmental stages of copepods that are apparently favoured by slightly older cod larvae (Ellertsen et al. 1980). On Georges Bank, the developmental stages of Pseudocalanus spp. constitute greater than $60 \%$ of the biomass consumed by the youngest cod larvae (Kane 1984), but in the arctic and sub-arctic waters of the eastern Atlantic, the eggs and nauplii of the larger Calanus finmarchicus are usually favoured (Ellertsen et al. 1981, Skreslet 1989). Regrettably we lack detailed dietary information for larval cod off Newfoundland.

Hjort (1914) also recognized that larval cod, with only limited swimming ability, were extremely vulnerable to advective processes. Recognition of this fact led to the evolution of a second major hypothesis about the environmental conditions contributing to the success or failure of a stock prior to recruitment. The 'member/vagrant' hypothesis (Sinclair 1988) incorporates elements of match/mismatch with the additional concept that larvae will tend to be aggregated in areas favourable to their survival and growth, which are defined as 'larval retention areas'. Such areas may include large gyres, such as those associated with Grand Banks or Georges Bank, which can be further constrained by coastal fronts where water masses of somewhat different physical properties come in contact with each other, or they may be relatively small, partially isolated coastal inlets such as those found on the Labrador coast. Even the fronts, if relatively persistent, can be classified as 'larval retention areas' where the copepod prey also accumulate and reproduce in response to more or less continuous phytoplankton production. The 'members' of large, physically defined ecosystems are often defined as a 'stock' and, in time, they may acquire genetic distinctiveness such as specific spawning times and perhaps morphological differences (Iles \& Sinclair 1982). Here it may be important to mention that the northern cod stock (Divs. $2 \mathrm{~J} 3 \mathrm{KL}$ ) has recently been shown to be genetically distinct from that found on the Scotian Shelf (Pogson et al. 1993). In any event, once they are removed from their retention areas, the 'vagrants', being at a nutritional disadvantage, are probably lost, but a few hardy survivors may maintain some gene flow between neighbouring populations distributed over the wider area of a species' geographical range.

\section{Physical oceanography and global climate}

We now will attempt to link physical oceanography and arctic climatology as they may be affecting the ecosystem that normally leads to the production of northern cod. The earth's atmosphere is behaving like a giant greenhouse, wherein certain gasses, some of which have accumulated in the earth's atmosphere as a result of human activity, permit short wavelengths of solar radiation to penetrate to the surface but inhibit back radiation of longer wavelengths (Mitchell 1989). As the earth's atmosphere warms, it should follow that the oceans should likewise become warmer, but this does not necessarily occur everywhere (Clarke 1992).

The earth's atmosphere and its oceans are highly interactive such that there are major wind-driven surface currents around the equator. Also more radiant energy strikes the ocean surface at low latitudes than at high. In the North Atlantic, currents and absorbed heat are deflected north by the North American land mass forming a western near-surface boundary current, the Gulf Stream, and this warm, salty water keeps northern Europe decidedly warmer than is Canada at the same latitude (Schmitz \& McCartney 1993). However, the North Atlantic and Arctic Ocean effectively form a giant cul-de-sac (Fig. 2A), leaving the warm, salty surface current virtually no place to go but down as it is cooled and convectively mixed by northwesterly winds from Greenland and arctic Canada. Some of this water travels north through Fram Strait sinking beneath the Arctic Surface Water to form the Atlantic Layer. Another portion is mixed with varying amounts of deep, intermediate and surface water of arctic origin (Fig. 2B), mainly in the Norwegian and Greenland Seas, producing Greenland Sea Deep Water by deep convection in sufficiently cold years. The details of these processes are still incompletely known (Clarke et al. 1990), but they take place behind the barriers formed by the Greenland-Scotland ridges (Fig. 2B). The deeper waters are too dense to exit over these barriers and it is Arctic Intermediate Water which fills the relatively small Icelandic and Norwegian Basins (Aagaard et al. 1985). These basins have a rather short retention time ( 2 to $10 \mathrm{yr}$ ), and, because they are relatively small, they can be more easily influenced by transient climatic events (Aagaard et al. 1985). The overflow from these basins contributes to the formation of the North Atlantic Deep Water and drives the thermohaline 'conveyor belt' circulation (Fig. 3).

Why does the conveyor run in this direction? Could it ever be reversed? The answer to the first question is that there is an excess of salt in the northern North Atlantic that can best be removed by cooling and sinking. And, yes, it almost certainly was reversed during past glaciations, according to Broecker \& Denton (1989). They have calculated that the atmospheric transport of freshwater from the Atlantic to the Pacific is in the range of $0.35 \pm 0.10$ Sverdrups $\left(1 \mathrm{~Sv}=10^{6} \mathrm{~m}^{3}\right.$ $\left.\mathrm{s}^{-1}\right)$, most of it in mid-latitudes. A significant reduction 


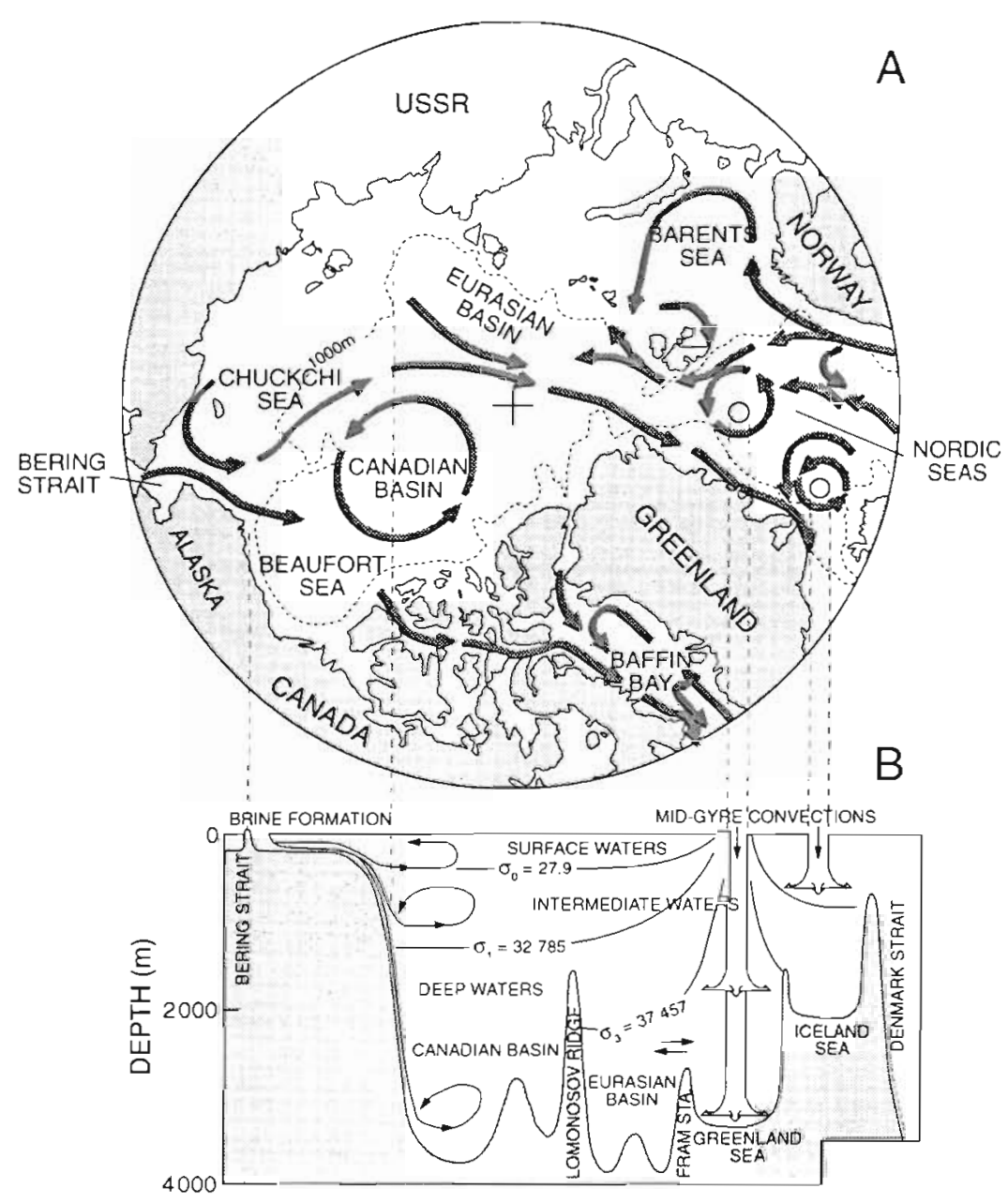

Fig. 2. The arctic mediterranean showing (A) major currents and (B) the locations of important processes and events which contribute to the thermohaline circulation of the global ocean. Redrawn from Aagaard et al. (1985) and Aagaard \& Carmack (1989)

in this transport would threaten the present thermohaline circulation thereby reducing northward transport of warmer, less dense water that would normally replace it. At the very least, a considerable cooling of the climate of northern Europe would result.

While there is no clear evidence of a recent change in evaporative transport, a second process, potentially affecting the thermohaline circulation of the global ocean, occurs only at high latitudes, and would seem to be critical to understanding climatic events affecting coastal waters. The formation of ice, by a process comparable to distillation, acts like the atmospheric transport of fresh water at lower latitudes to produce an excess of salt that favours deep convection in the Greenland, Iceland and Norwegian (Nordic) Seas (Aagaard \& Carmack 1989), and also deep water formation on the arctic continental shelves (Fig. 2B). However, the freshwater budget for the Arctic Ocean, including runoff, yields a positive balance such that global warming can produce the rather unexpected effect of oceanic cooling (Clarke 1992). Fresh water released from melting ice dilutes the warmer but more saline waters entering the Nordic Seas as part of the conveyor belt circulation, thereby increasing stratification. The consequence is reduced convection and reduced thermal ventilation. Indeed, Aagaard \& Carmack (1989) have suggested that the Greenland and Iceland Seas, and probably also the Labrador Sea, are 'rather delicately poised' between conditions favouring convective mixing and those reducing it!

\section{Temperature, salinity and climate in the Northwest Atlantic}

These comments are intended to introduce the Great Salinity Anomaly (GSA) and its far-reaching consequences. The origins of this phenomenon are still being debated but, from about 1964 through to 1971 , there were persistently lower than normal temperatures and salinities in the Nordic Seas (Dickson et al. 1988). Over the same period, there were also large, positive sea-ice anomalies in the Greenland Sea which were attributed to increased terrestrial runoff into the Arctic Ocean from North America a few years earlier (Mysak \& Power 1991, 1992, Häkkinen 1993). Apparently the usual pattern of deep convection in this part of the North Atlantic had broken down; instead the GSA developed, with unusually low salinity and lower than normal temperatures, and, in 1968, began a 14 yr counterclockwise circuit around the North Atlantic, returning to the Greenland Sea just north of Iceland in 1982 (Fig. 4). The effect of its passage on recruitment of several North Atlantic fish stocks was profound. Note that both the Grand Banks (Div. 3NO) and West Greenland cod showed poor year classes during the early 1970s. Of the 15 North Atlantic stocks examined, 11 were significantly affected by the passage of the GSA (Cushing 1988, 1990).

In a recent re-analysis of data generated in response to the GSA, Mertz \& Myers (1994) addressed several issues which had arisen from previous studies. They 


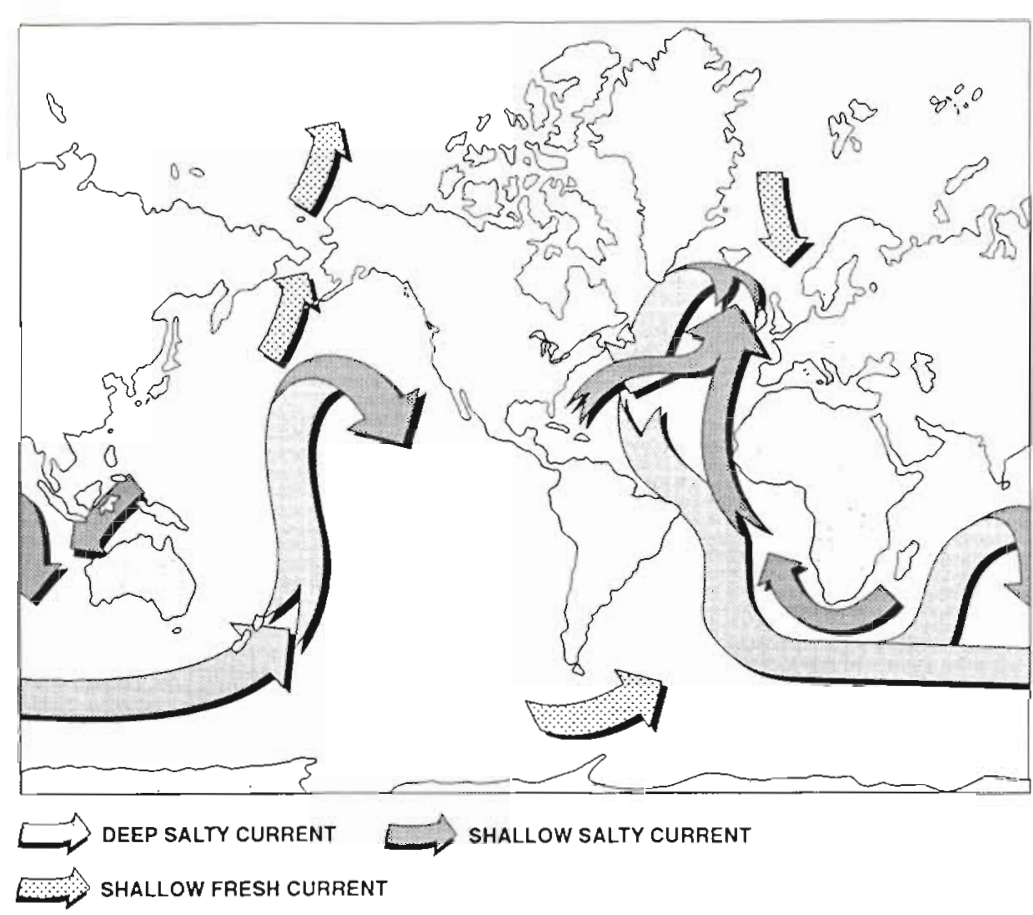

Fig. 3. A large-scale salt transport system operating in today's ocean compensates for the transport of water (as vapour) through the atmosphere from the Atlantic to the Pacific Ocean. Huge reservoirs of polar ice also contribute to the excess salt in the northern North Atlantic. In any event salt-laden deep water formed in the north flows down the length of the Atlantic around Africa through the southern Indian Ocean and finally north in the deep Pacific Ocean. Redrawn from Broecker \& Denton (1989)

anomalies through the 1920 s and 1930 s. There was more ice in the 1940 s and again in the 1960 s just before the initiation of the GSA. Mysak et al. (1990) suggest that an interdecadal oscillation with a period of 10 to $15 \mathrm{yr}$, described by a negative feedback loop (Fig 5), is controlling sea ice and convection in the Greenland, Iceland and Norwegian Seas. Smidt's (1989) sea surface temperature (SST) observations are particularly revealing because they also show that there was virtually no cod fishery in West Greenland waters following cold events prior to 1920 until well into the warm period of the 1930 s.

As in the Nordic Seas, deep convective mixing can also occur in the Labrador Sea forming Labrador Sea Water (LSW) at intermediate depths (Clarke \& Gascard 1983). There is evidence for cooling and freshening of LSW during 1971-1976 and again in 1984-1990, and that this water is apparently being advected around the North Atlantic more slowly than was the GSA. It took 18 to $19 \mathrm{yr}$ for LSW formed in 1972 to reach the Rockall Trough just northwest of Ireland (Read \& Gould 1992). The LSW formed in the mid1980 s is cooler and fresher than that of

reaffirmed the apparently major effects of GSA passage on recruitment of West Greenland cod and several Grand Banks cod stocks, notably 2J3KL, 3M and 3Ps. Curiously, the 3NO stock (Fig, 4), which Cushing (1988) found to be significantly affected by the passage of the anomaly, was found by Mertz \& Myers (1994) to have the poorest correlation with the GSA salinity signal, using several different recruitment indices. They have also shown that reduced sea temperatures were not well correlated with the GSA and therefore reduced salinities should not be used as a proxy for low temperature in the Grand Banks area. Nor was there clear evidence that GSA-associated conditions significantly affected production cycles of either phytoplankton or copepods, i.e. there was no obvious food scarcity that might have affected cod recruitment.

An important question is whether the GSA was a one-time climatic event. Several investigators, including Dickson et al. (1988), Smidt (1989) and Mysak et al. (1990), have looked at lengthy data sets from several different sources, concluding that similar events have occurred in the past. Large positive ice anomalies and reduced salinities prevailed for at least a decade in the early part of this century followed by negative ice
1972 suggesting that the sub-arctic North Atlantic should continue to cool and freshen. Cooling and freshening in the upper water column are happening in the vicinity of the Grand Bank at present (1990-1994; Prinsenberg \& Peterson 1994).

The Labrador Current (LC) is the principal vector of favourable or unfavourable conditions to the environment of the northern cod (Fig. 6). Being the continuation of the Baffin Current, it brings a large but unknown amount of cold, fresh water from the Canadian Archipelago and incorporates a large freshwater output from Hudson Strait and the usually warmer, more saline West Greenland Current (WGC) (Mertz et al, 1993). On the shallow Labrador Shelf, the LC is partitioned into a cooler, less saline inshore stream $(-15 \%$ of the transport) and the larger slope component with $-85 \%$ of the roughly 4 to $5 \mathrm{~Sv}$ total. Between the streams there is a strong front separating the fresher Baffin Bay water (and Hudson Strait water) from the slope water component. Both branches show considerable variance on an annual and interannual basis (Lazier \& Wright 1993). Most of the variance in salinity would seem to be associated with the inner (shelf) component of the LC but the WGC would seem to be 

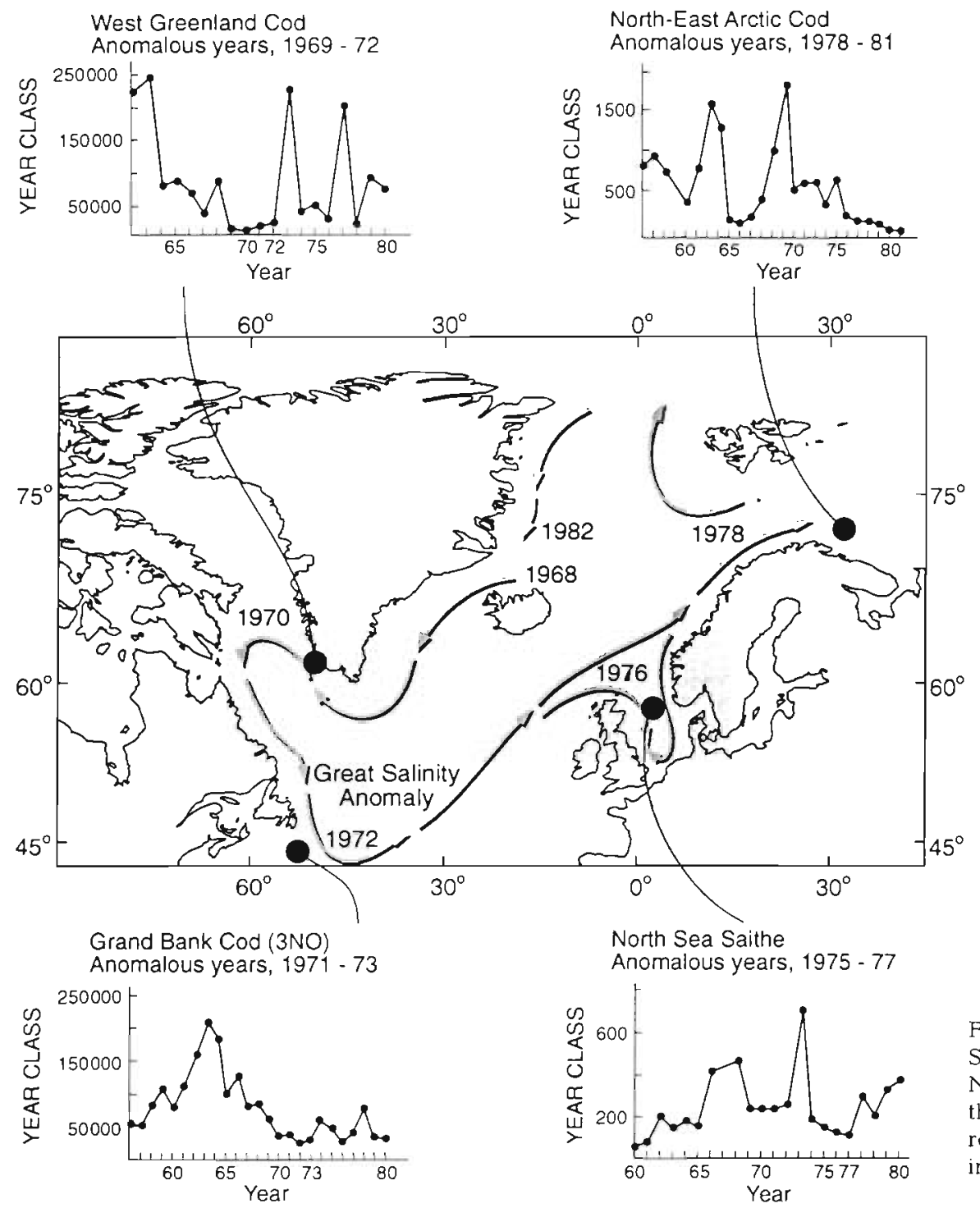

Fig. 4. Approximate path of the Great Salinity Anomaly (GSA) around the North Atlantic, showing the effect of the anomalous years on year class recruitment for several stocks in passing. Partially redrawn from Cushing (1988)

the principal vector of freshwater anomalies associated with reduced convection in the Nordic Seas. In this regard, Schott et al. (1993) reported that convective activity was weak and confined to intermediate depths in the winter of 1988-1989 in the Greenland Sea. How long might it be before this 'potential anomaly' affects the Labrador-Grand Banks system? Indeed this may be what is happening on the Grand Banks now. In the Nordic Seas, Mysak \& Power (1992) have already designated anomalous reductions in temperature and salinity of the middle 1980 s as a 'Great Ice and Salinity Anomaly'. During the GSA, a 4 yr lag between events in the Nordic seas and those in the Labrador Sea was observed (Mysak \& Manak 1989), so the timing for a new anomaly to hit the Grand Banks is about right!

The variability in the amount of seasonal ice transported along the Labrador shelf to the Grand Banks region in the wirter-spring period is large. Understanding the importance of ice as a variable in the habitat of northern cod is probably fundamental to developing a management strategy that could provide some hope of a sustainable fishery. The distribution of sea ice in the Northwest Atlantic has been recorded in some form for more than 100 yr (Mysak et al. 1990). Good quality ice information for the Labrador SeaGrand Banks area has been available since 1953 (Chapman \& Walsh 1993). However, the precision of such information is not so important for long-range prediction of favourable conditions for cod recruitment as is knowing the origins of the ice and its interannual variability.

As mentioned earlier sea-ice anomalies in the Greenland and Labrador Seas may have an interdecadal climate cycle of 10 to $20 \mathrm{yr}$ and may also be 
correlated with runoff into the western Arctic Ocean (Mysak et al. 1990, Mysak \& Power 1991, 1992). Runoff from major Siberian rivers could also affect SST fluctuations in the northern Atlantic (Peng \& Mysak 1992), and probably ice conditions. Interannual variations of summer runoff into Hudson Bay were negatively correlated with salinity anomalies on the Newfoundland shelf with a 9 mo lag, but sea-ice extent was primarily responsible for salinity fluctuations there (Myers et al. 1990). However, sea-ice anomalies in the northern North Atlantic could also be driven by wind, low temperature and ocean currents (Ikeda 1990, Agnew 1993); Ikeda also found evidence for decadal oscillations in that air-ice-ocean system. Similarly, Prinsenberg \& Peterson (1994) found that interannual variability in sea ice on the Labrador Shelf was related to anomalies in atmospheric circulation in the Northern Hemisphere described by the North Atlantic Oscillation Index, i.e the difference in the average winter atmospheric pressure at sea level between the Azores and Iceland, which is a measure of the frequency and strength of northwesterly winds. These new data imply

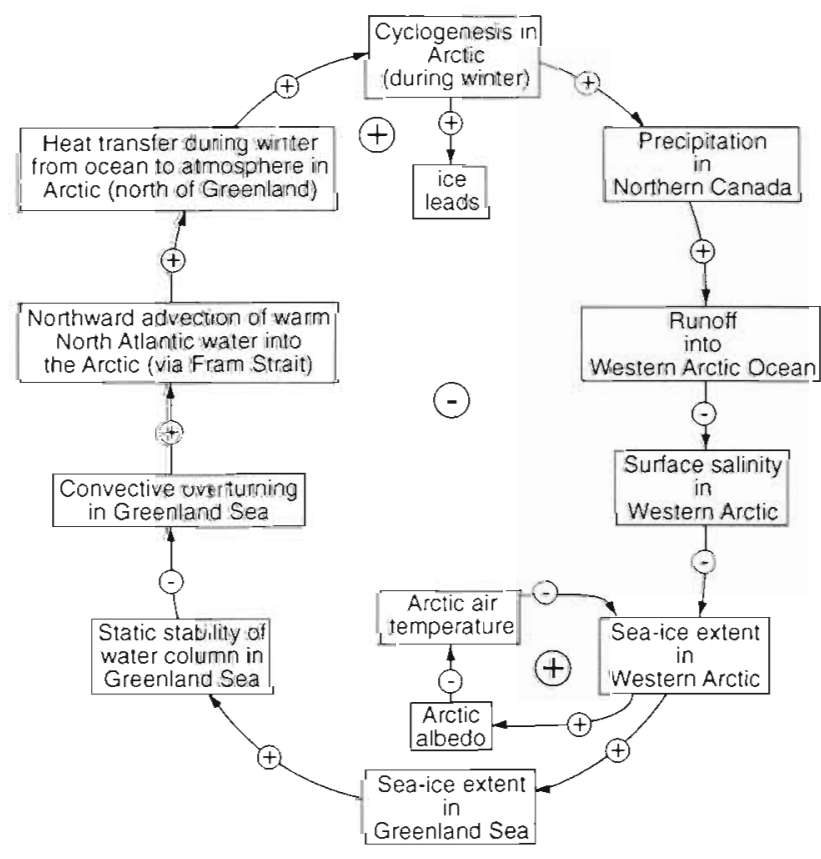

Fig. 5. Possible negative feedback loop linking arctic cyclonic activity, precipitation, runoff, salinity, sea-ice extent, oceanic stability, convective overturning, poleward oceanic heat transport and heat flux into the atmosphere. The lower small positive feedback loop involving arctic air temperature is the familiar ice-albedo feedback mechanism which could assist in the cooling of the troposphere if ice extent increases. The upper small teedback loop involving ice leads results in the intensification of cyclonic activity if the area of ice leads increases (Maslanik \& Barry 1989). Redrawn from Mysak \& Power (1991)

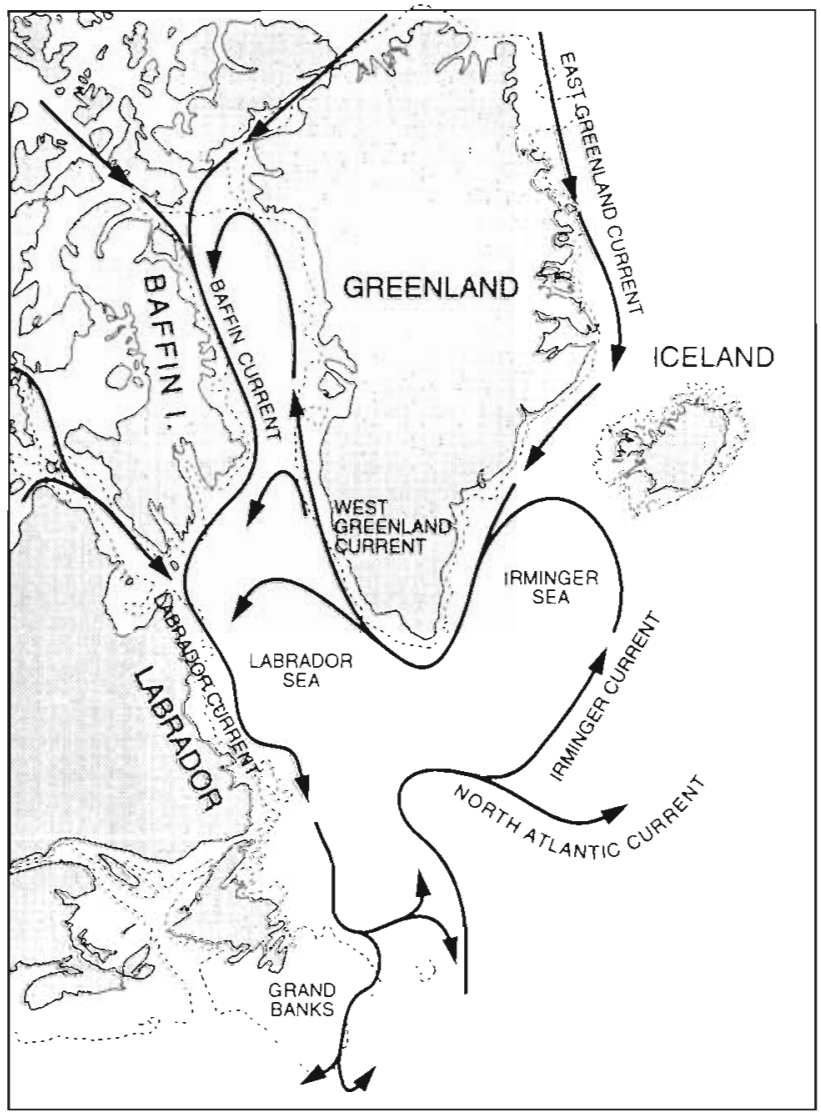

Fig. 6. The Arctic-Grand Banks connection showing major current systems contributing to the environment of northern cod Gadus morhua

that sea-ice anomalies may be occurring even more frequently than every decade (S. J. Prinsenberg pers. comm.).

\section{DISCUSSION}

On the basis of this rather brief overview of global climate and its interactions with the oceanic environment of northern cod, cooling, freshening and, above all, uncertainty about future conditions can be expected for a few years or even decades. If we accept that anomalously cold and fresh conditions do not provide the best conditions for cod propagation and growth (and not everyone accepts this hypothesis!), one question still to be answered is just how recruitment is negatively affected. We now briefly examine several papers that have used statistical or mathematical modelling to evaluate some of the physical or biological factors thought to influence cod distribution and/or availability. Myers \& Drinkwater (1988/1989) examined the possibility that Ekman transport driven 

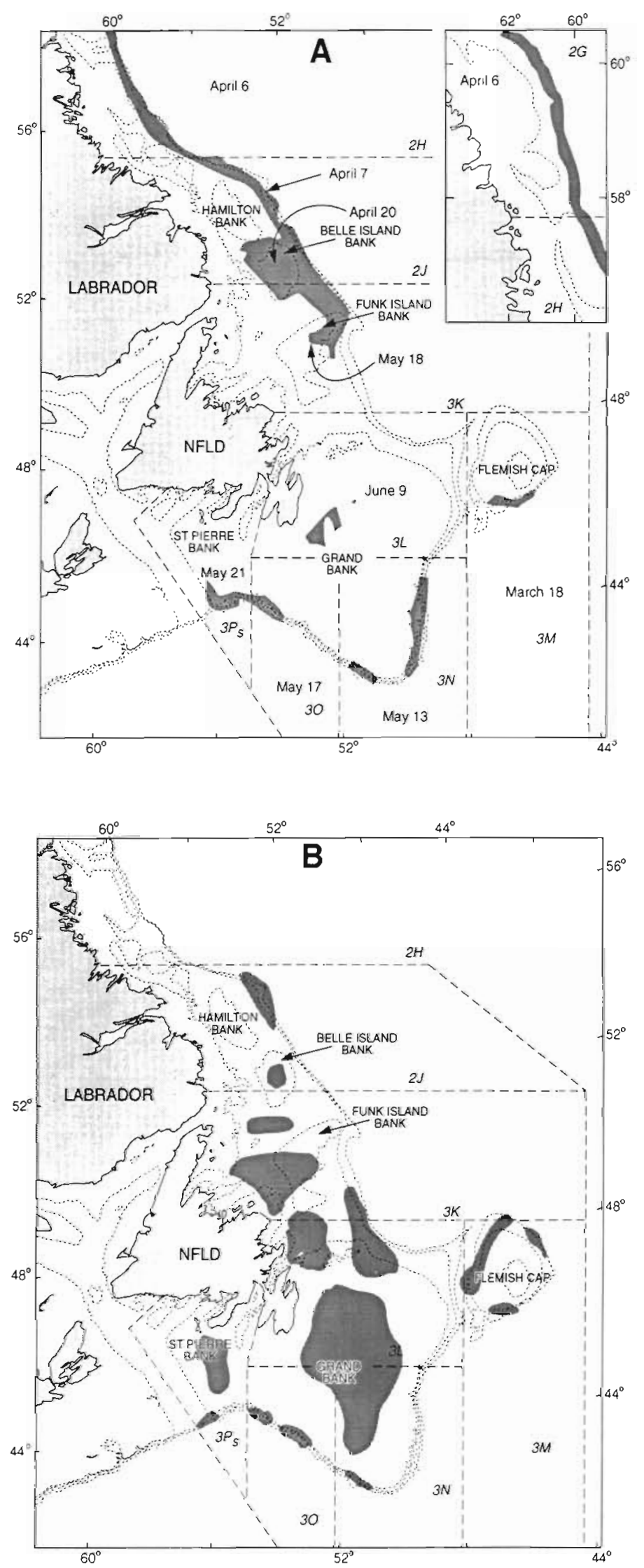

by long-shore winds might carry fish eggs and larvae offshore and away from favourable feeding conditions. Their model suggested that vertical migration by larvae would lessen the chance of being transported offshore relative to those that remained in the mixed layer continuously, but they found no evidence that Ekman transport of cod eggs and larvae affected recruitment. In a somewhat similar study, Helbig et al. (1992), by simulating potential drift patterns for developing larvae, found evidence that individual stocks could remain discrete in their drift over the banks without utilization of retention sites, such as bays on the Labrador coast or the Southeast Shoal of the Grand Banks. Their model also showed potential for assessing the effects of different wind fields, and even individual storms, on larval drift and dispersal.

In still another study, Myers et al. (1993a) analyzed the time of cod spawning and found no obvious association with latitude. In Fig. $7 \mathrm{~A}$, their 'mean spawning times' have been added to a chart of spawning areas prepared by Fitzpatrick \& Miller (1979). However, a more recent analysis of cod spawning data from the Newfoundland area suggests that the earlier observations on which Fig. 7A was based relied too heavily on sampling in the slope waters off the Grand Banks rather than on them (Hutchings et al. 1993). A new evaluation of spawning areas shows that with few exceptions most northern cod spawn on banks rather than in slope water (Fig. 7B). Their new data, which included information from a number of inshore locations not previously analysed, may also influence the mean spawning dates of cod in different management zones, although it probably does not invalidate the supposition that many northern stocks initiate reproduction earlier than their more southern counterparts. Hutchings \& Myers (1993) report that older cod of both sexes initiate spawning later and remain in spawning condition longer than do younger ones, which would presumably increase the probability of a

Fig. 7. Spawning locations (dark shaded areas) of major cod Gadus morhua stocks on the Labrador-Grand Banks shelf ecosystem. (A) The dates associated with the management zones are the mean dates of spawning calculated by Myers et al. (1993a). Redrawn from Fitzpatrick \& Miller (1979). (B) Recent revision of the spawning locations for northern cod based on the data and observations of Hutchings et al. (1993). Labels in italics are NAFO divisions. Three depth contours are shown. Innermost is 100 fathoms, middle is 200 fathoms, outer is 1000 fathoms $(183,366$ and $1892 \mathrm{~m}$ respectively) 
'match' rather than a 'mismatch' for some first-feeding offspring of older stock. But there is also evidence of a major reduction in numbers of older spawners relative to younger ones from the $2 \mathrm{~J} 3 \mathrm{~K}$ stock over the past 30 yr.

As mentioned earlier, Mertz \& Myers (1994) did not find a clear relationship between cod recruitment and the abundance of young stages of Calanus finmarchicus. As shown by Myers et al. (1993a), cod spawning time, which is earlier in the northern stocks, seemed to be out of phase with the peak of zooplankton availability which appeared first in the south. However, the fit was improved when the correlations were made between the estimated time of appearance (hatching time) of the first-feeding larvae, calculated from Fig 6 in Page \& Frank (1989), although the NAFO region 1 and 2 animals would still 'mismatch' by about 30 to 40 d. As pointed out by Myers et al. (1993a), such estimates are relatively imprecise because of the rapid increase in development time with temperature at low temperatures and uncertainty of the temperature regime over 30 to $60 \mathrm{~d}$ of drift extending 600 to $1000 \mathrm{~km}$ along the Labrador-Newfoundland coast (Lear \& Green 1984). Even after they have hatched northern cod are larger, swim less, are more efficient in energy utilization and are generally 'cold adapted' in comparison with southern stocks (Hunt von Herbing 1994).

Of regularly sampled physical variables, only salinity showed a clear positive correlation with recruitment for a number year classes of different cod stocks (Myers et al. 1993b). Earlier, Sutcliffe et al. (1983) argued that increased salinity reduced stratification and encouraged mixing, thereby maintaining sufficient nutrients for continued primary production along the Labrador Shelf. However, there is no evidence that water temperature influences northern cod recruitment on Grand Banks (R. A. Myers pers. comm.), although the effects of temperature may be confounded by a strong seasonal signal associated with sea ice (Mertz \& Myers 1994, Prinsenberg \& Peterson 1994). In the Barents Sea, year class strength of cod seems to be well correlated with temperature (reviewed by Dickson \& Brander 1993).

So why and how have northern cod stocks become decimated at least twice in the past few decades (Fig. 1)? Overfishing is an obvious explanation, and yet why should the spawning stock biomass become diminished successively in different stocks of several fish species around the North Atlantic in association with an apparently unique set of climatically related oceanographic conditions such as the GSA unless these conditions also contributed in some way to the demise of the stock? In seeking an explanation we first make the assumption that something has negatively affected northern cod recruitment. We point out that northern cod are near or at the northern limit of their range off West Greenland and on the northern Labrador Coast (Dickson \& Brander 1993). Considerable adaptability must be shown by the cod living in such regions, but keep in mind that adaptations are genetic and might take some time to spread through sometimes remote populations if there were a sudden climatically related change in their environment. In this regard there is now some evidence that cod populations on each of the banks off Labrador are genetically discrete (Pogson et al. 1993), although we do not know what the rate of gene flow between these 'population units' may be.

The West Greenland cod stock is a perhaps somewhat exaggerated case in point. To our knowledge there has been no direct genetic comparison between Icelandic and West Greenland stocks, while the amount of genetic divergence between Norwegian stocks and those off Newfoundland would seem to be somewhat controversial (Carr \& Marshall 1991, Árnason et al. 1992). In any event, the cod fishery in this part of the world has been of a periodic nature for as long as records have been kept. There were apparently 2 short periods of cod abundance in the 19th century and then few cod for 50 to 75 yr. From roughly 1930 to the mid-1960s, there were increasing catches peaking at about $400000 \mathrm{t} \mathrm{yr}^{-1}$ just prior to the GSA. From 1955 to 1975, the spawning stock biomass in West Greenland waters declined, and it has remained very low even though there was a rather strong year class in 1985 (Hovgård \& Buch 1990). The important point here is that recruitment to the West Greenland banks in recent years is at least partially dependent on 'vagrants' from spawning grounds southwest of Iceland (Dickson \& Brander 1993, J. J. Engelstoft pers. comm.).

To further the discussion, we will now make some cross-ocean comparisons with another 'northern' cod population and its environment, the Barents Sea. In Fig. 8 are shown the distributions of currents, water masses and ice in the Barents Sea: prominent between Spitsbergen and Norway lies the Polar Front, which also roughly corresponds with the position of maximum southern extent of the arctic ice. More importantly this feature separates the Arctic Water from the warmer, saltier North Atlantic Water and partitions 2 quite distinct zooplankton communities. The Atlantic community is dominated by Calanus finmarchicus, which spawns in spring and has an annual life cycle (Tande 1991), but includes several smaller species, also spring spawners (Norrbin 1991). To the north of the front the dominant species is the arctic form $C$. glacialis, which has a 2 yr life cycle there (Tande et al. 1985). The smaller copepod species are also less com- 


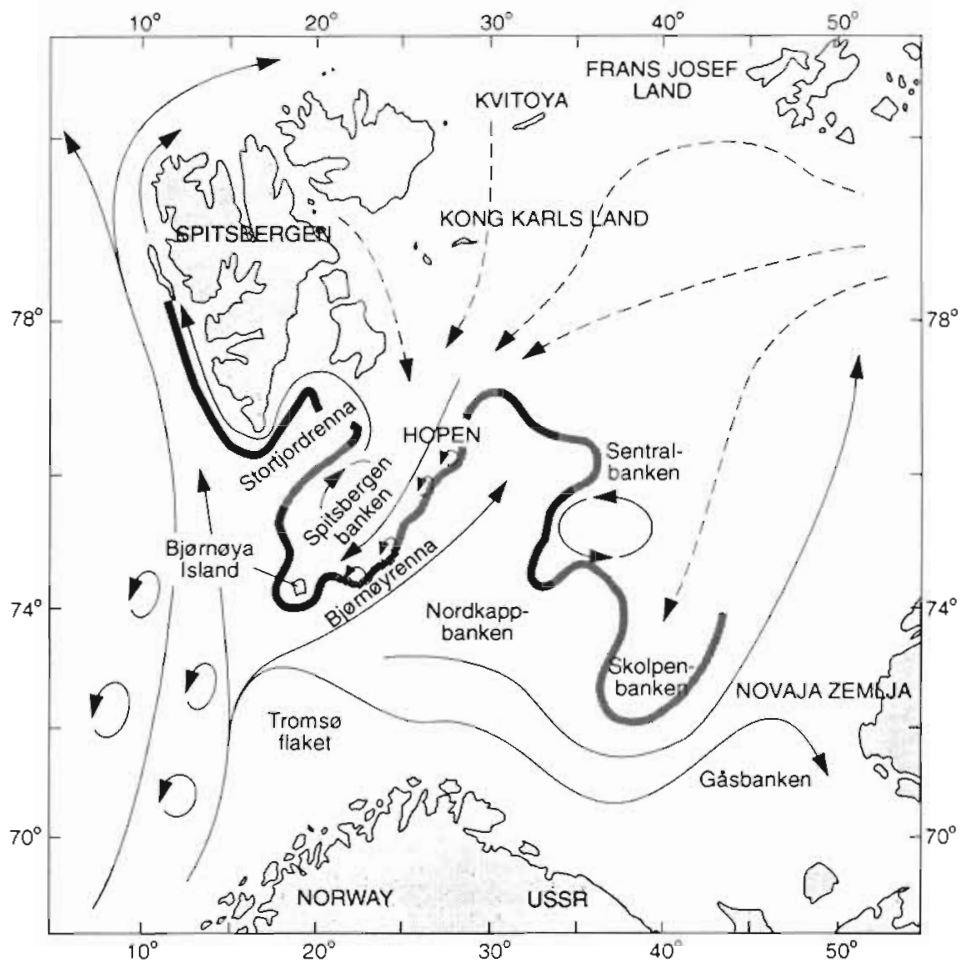

Fig. 8. Main current systems and water masses in the Barents Sea, showing also the mean position of the Polar Front as an alternating solid and stippled line. Redrawn from Loeng (1991)

mon (Hassel 1986), being often replaced by the early copepodids of C. glacialis (Tande 1991). C. hyperboreus occupies a somewhat enigmatic role, occurring on both sides of the front (Tande 1991). It is a large, lipid-storing species which spawns without feeding before the spring phytoplankton bloom (Conover 1988).

On the western side of the Atlantic, we have a somewhat analogous system, complete with a 'Polar Front' that separates the predominantly arctic, shelf component of the Labrador Current from the slightly warmer, saltier slope water component. The parallel extends to the Calanus populations as well (Fig. 9), there being plenty of C. finmarchicus in the Atlantic water (Huntley et al. 1983, Anderson 1990), while those on the inner Labrador Shelf and incidentally in Hudson Bay and in the interior of the Archipelago, are virtually all C. glacialis (Huntley et al. 1983, Rochet \& Grainger 1988, and Conover 1988 respectively). As in the Barents Sea, $C$. hyperboreus is found on both sides of the front.

As mentioned above, the young stages of Calanus finmarchicus are a favourite food for northern cod larvae (Skreslet 1989). To continue the high latitude comparisons, near the Polar Front in the Barents Sea, C. finmarchicus has begun spawning by April 1, even under the ice. Once the pycnocline was well established both eggs and chlorophyll were concentrated in the mixed layer. Calanus nauplii were abundant by mid-May, also above the pycnocline where their food supply (i.e. chlorophyll) was still abundant (Melle \& Skjoldal 1989). Reproduction in C. glacialis in the same general environment was about 1 mo later and may be spread over a longer period (Tande et al. 1985, Tande 1991).

Similarly, off Flemish Cap, eggs and nauplii of Calanus finmarchicus were already abundant over a $400 \mathrm{~m}$ water column by April 7 to 14, 1980 (Anderson 1990). Here there is also a cod stock (3M) that spawns in March-April (Fig. 7A). Using recurrent group analysis, Huntley et al. (1983) showed that copepod stages I and II (CI and CII) of $C$. finmarchicus appeared in the West Greenland drift of the Labrador Sea in May, about 1 mo before $\mathrm{CI}$ and CII of C. glacialis, and most stages of Pseudocalanus spp., were found in numbers on the Labrador Shelf. Under the ice in southeastern Hudson Bay, egg production by C. glacialis commenced in May, about $3 \mathrm{wk}$ after the initiation of the ice-algal bloom, but peak fecundity developed in June after the ice had begun to melt (Tourangeau \& Runge 1991)

There are some important differences between the Barents Sea ecosystem and that off Labrador, however. In the Northeast Atlantic the water masses have a north-south orientation separated by a polar front that lies roughly east and west. That in the Northwest Atlantic is oriented differently by about $90^{\circ}$ with a polar front running north and south and water masses to the east and west of it. The Barents Sea is rather open and its front is relatively remote from the Norwegian coast along which most northern cod larvae are spawned. Their development takes place entirely in Atlantic water with ample young stages of Calanus finmarchicus to support their growth. Off Labrador spawning primarily takes place on the offshore banks and even in coastal inlets, usually at depths less than $300 \mathrm{~m}$ and in Atlantic water (Hutchings et al. 1993), but the polar front can actually lie between the spawning cod and the surface layers. The 2J3K stock frequently spawns under the seasonal ice, which makes sampling for spawning individuals uncertain (Hutchings et al. 1993). The developing eggs and the first-feeding larvae are buoyant so quite possibly they would penetrate the polar front into sub-zero Arctic water during early development where their food supply is less likely to be the developmental stages of $C$. finmarchicus. However, the major difference between the 2 systems is in 


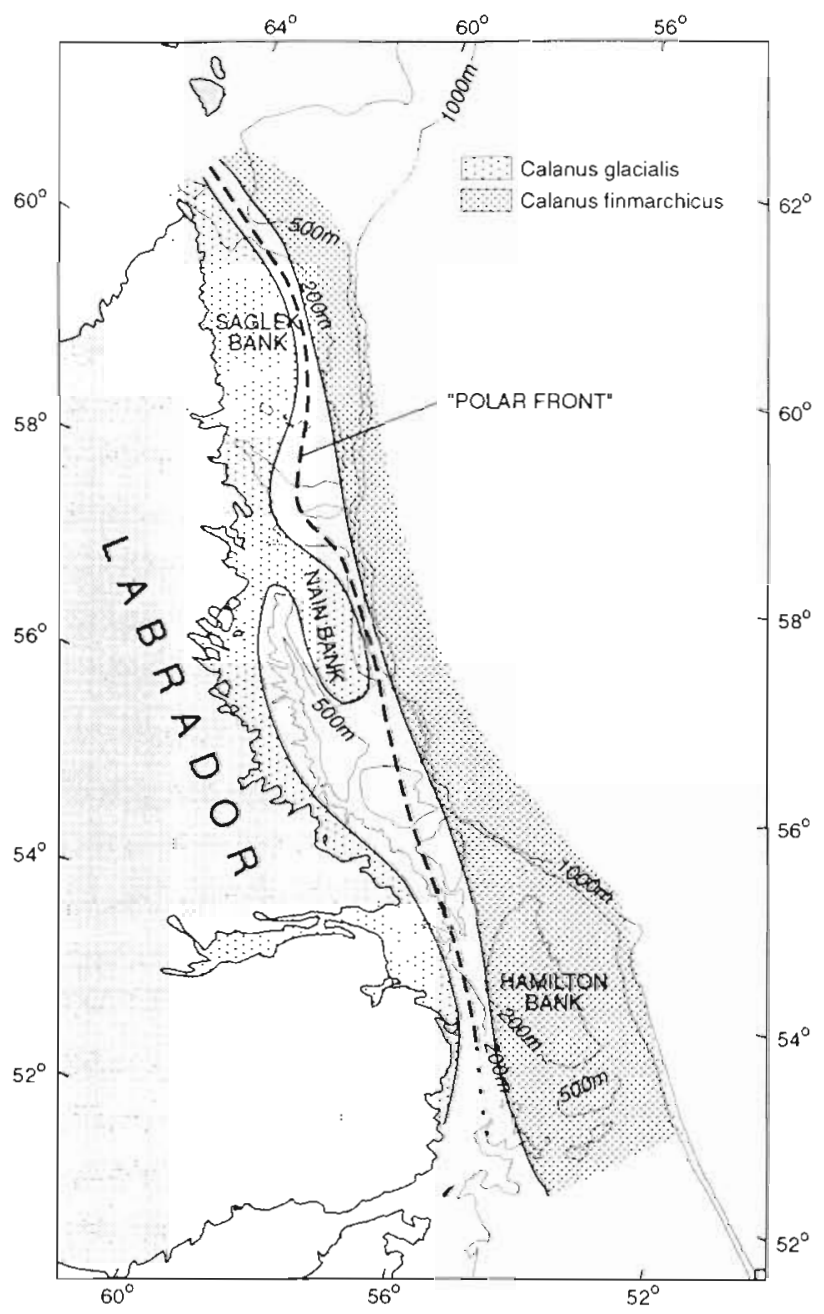

Fig. 9. Distribution of copepodid stages 4 and 5 of Calanus glacialis and C. finmarchicus on or near the Labrador Shelf during the first $2 \mathrm{wk}$ of September 1985, showing also the approximate position of the Polar Front as a dashed line separating the inner (bank) and outer (slope) branches of the Labrador Current

their relationships to the major oceanographic and atmospheric events that affect the fish populations. In the Barents Sea the climatic system is largely dependent on the influx of relatively warm Atlantic water and at least partially regulated by a locally driven feedback cycle (Ådlandsvik \& Loeng 1991). Hence the possibility of long-range prediction there would seem remote in the present state of our understanding of oceanic-atmospheric linkages. But in the Northwest Atlantic several water masses of polar origin control the environment of the northern cod as we have tried to show in this paper. Furthermore, these water masses are 'tagged' with and greatly influenced by ice, which is relatively easy to measure remotely (Massom 1991) and seems to respond to climatic events with possibly predictable or at least measurable lag periods (S. J. Prinsenberg pers. comm.).

Clearly the case is not proven, but we argue here that the large positive ice anomalies, with cold, less saline conditions currently being observed in Newfoundland-Labrador waters (Prinsenberg \& Peterson 1994), have increased the likelihood of a 'mismatch' between larval cod and their preferred food, copepod eggs and nauplii. For example, early spawning cod stacks (3M, 2GH; Fig. 7) probably evolved under the influence of warmer waters to the east of the 'Polar Front' (Fig. 9) where Calanus finmarchicus is the dominant grazer (Huntley et al. 1983), and its offspring probably provides cod larvae their early food supply. Further south, cold water and ice could delay the onset of a spring phytoplankton bloom, even though melt water would provide additional stability along an ice edge (Smith 1987). It apparently has pushed the polar front further east, placing the spawning grounds of some stocks (e.g. 2GH, 2J3K; Fig. 7) in arctic (C. glacialis) waters rather than boreal (C. finmarchicus) waters, and driving most older cod to depths greater than $400 \mathrm{~m}$ (Bishop et al. 1994). We do not know if the nauplii and younger copepodids of $C$. glacialis are a suitable food for cod larvae, but they would seem to be in an acceptable size range (Ellertsen et al. 1980). However, the available information on reproduction in the northern Northwest Atlantic suggests that $C$. glacialis and Pseudocalanus spp. breed later relative to the appearance of first-feeding cod. It could be argued that the later the spawning season of the northern cod, the shorter the productive window (which could also be at suboptimal temperature for growth!) within which the young cod must grow and achieve the best possible condition factor prior to overwintering.

Can we understand global changes in climate, either of relatively short duration (interdecadal, decadal, etc.) or longer, whether or not they may be influenced by 'greenhouse' warming, well enough to use this information to manage major fisheries? There is too much at stake to continue overexploiting fishery resources and then to impose a 'moratorium' on fishing while waiting for nature to cure itself. There are almost certainly atmospheric and oceanographic events that can be used to predict suboptimal periods in the environment of northern cod, regardless of their periodicity, but sufficiently far in advance to prevent serious depletion of the stocks. The same suggestion has been made recently by Greatbatch (1994). To quote him, 'Perhaps it might even be possible to foresee collapses in fisheries, such as currently being experienced in the waters off Atlantic Canada'. We must learn to recognize the symptoms, and the earlier the better. High latitude ice conditions and SST, perhaps as indicators of interdecadal, or shorter, climate variability, can be rou- 
tinely monitored by satellite (Massom 1991) and subsequently modelled, perhaps using Fig. 5 as a conceptual basis. Forecasting future climate-related oceanographic conditions may become routine some day, and perhaps as accurate as contemporary weather forecasting.

It should also be useful to look at the composition of the copepod community, especially at regularly sampled stations, as an indicator of the origin and recent thermal history of a water mass, and possibly also to predict potential food supply for larval cod. The late stages of the 2 Calanus species are recognizably different on the basis of size and pigmentation when they are alive (Plourde \& Runge 1993, Conover pers. obs.). We hope to develop a Calanus colour monitor based on this concept. Experimental investigations of the reproductive potential of the 2 species within the present range of the northern cod were initiated during the spring of 1994, but as yet there are no definitive data.

\section{CONCLUSIONS}

Most maps of the northwestern Atlantic Ocean do not clearly show the geographic and oceanographic linkages of the Labrador Sea and Grand Banks with the Canadian High Arctic. This is unfortunate because a large and variable quantity of fresh water becomes associated with the Labrador Current by transport through Lancaster Sound, Jones Sound and Nares Strait into Baffin Bay, whence it forms the Baffin Current, while additional, and variable, amounts of fresh water enter from Hudson Strait and via the West Greenland Current from the Greenland and Iceland Seas. In transit this water is repeatedly, and usually temporarily, arrested by winter freezing, during which time it can be readily monitored by satellite. We believe that cold, fresh anomalies, which are directly related to the amount of previously accumulated freshwater in the form of ice and which appear with interdecadal, and perhaps shorter, periodicity, are in some way responsible for major fluctuations in recruitment in the northern cod stocks.

The northern Labrador Shelf is relatively narrow and the Labrador Current consists of a shelf and a slope component. Water of arctic origins makes up most of the shelf component and Atlantic water generally predominates in the slope component, such that a 'polar front' divides the current into 2 portions.

Based largely on experimental research with socalled 'arctic' cod in the Barents Sea, it is known that cod spawn in Atlantic water and require access to suitable prey, usually in the form of the younger developmental stages of the copepod Calanus finmarchicus, an Atlantic species, within a few days of hatching to sur- vive. Cod eggs are buoyant, and when the spawning of the cod and the copepod occur in the proper sequence, recruitment is usually good and a 'match' is observed. If the timing is not perfect, the larval cod may not thrive and a 'mismatch' is said to have occurred.

In analogous fashion, larval cod are also produced in Atlantic water, usually on the banks off Labrador and on Grand Banks, and when conditions are favourable they will also find a match of suitable copepod developmental stages in the near-surface waters where they will develop successfully. However, when the arctic component of the Labrador Current is considerably augmented by cold, fresher water from further north and east, the polar front is also pushed to the east, perhaps driving the spawning cod completely off the banks and/or capping the Atlantic water in which the cod eggs are laid. In either case, the buoyant eggs and larvae will penetrate through the polar front and attempt to develop in arctic water. Here the dominant copepod is Calanus glacialis, which spawns at least a month later than its Atlantic congener. Hence the chances of a mismatch are much increased. In addition to regular monitoring of ice conditions 'upstream' in the Labrador Current, we recommend regular plankton sampling, believing that the C. glacialis/C. finmarchicus ratio should have value as an index of potential recruitment success for northern cod.

Acknowledgements. A number of our colleagues have read and commented on the manuscript. In alphabetical order they include Ken Drinkwater, Jim Elliot, Ken Frank, Richard Greatbatch, Alex Herman, John Lazier. Steve McPhee, Ram Myers, Madhu Paranjape, Simon Prinsenberg, Jeff Runge, and Mike Sinclair. We are also grateful to Holger Hovgård for his detailed review and also to a second anonymous reviewer for his important contribution. Aspects of this paper have been discussed with Harold (Buster) Welch. He, and colleagues at the Freshwater Institute, Winnipeg, and the staff of the Polar Continental Shelf Project, at Resolute, N.W.T., have substantially assisted our arctic research over the years, making it enjoyable, as well as possible.

\section{LITERATURE CITED}

Aagaard K, Carmack EC (1989) The role of sea ice and other fresh water in the arctic circulation. $J$ geophys Res 94(C10): $14485-14498$

Aagaard K, Swift JH, Carmack EC (1985) Thermohaline circulation in the arctic mediterranean seas. J geophys Res $90(C 3): 4833-4846$

Addlandsvik B, Loeng H (1991) A study of the climatic system in the Barents Sea. In: Sakshaug E, Hopkins CCE, Øritsland NA (eds) Proceedings of the Pro Mare Symposium on Polar Marine Ecology, Trondheim, 12-16 May 1990. Polar Res 10(1):45-49

Agnew T (1993) Simultaneous winter sea-ice and atmospheric circulation anomaly patterns. Atmos-Ocean 31 $259-280$ 
Anderson JT (1990) Seasonal development of invertebrate zooplankton on Flemish Cap. Mar Ecol Prog Ser 67 : $127-140$

Anonymous (1994) Scientific Council Reports 1993. Northwest Atlantic Fisheries Organization, Dartmouth, NS, p $46-65$

Árnason E, Pálsson S, Arason A (1992) Gene flow and lack of population differentiation in Atlantic cod. Gadus morhua L., from Iceland, and comparison of cod from Norway and Newfoundland. J Fish Biol 40:751-770

Bishop CA, Anderson J, Dalley E, Davis MB, Murphy EF, Rose GA, Stansbury DE, Taggart C. Winters G, Methven D (1994) An assessment of the cod stock in NAFO divisions 2J + 3KL. NAFO SCR Doc 94/40

Broecker WS, Denton GH (1989) The role of ocean-atmosphere reorganizations in glacial cycles. Geochim Cosmochim Acta 53:2465-2501

Carr SM, Marshall HD (1991) Detection of intraspecific DNA sequence variance in the mitochondrial cytochrome $b$ gene of Atlantic cod (Gadus morhua) by the polymerase chain reaction. Can J Fish Aquat Sci 48:48-52

Chapman WL, Walsh JE (1993) Recent variations of sea ice and air temperatures in high latitudes. Bull Am Meteorol Soc 74:33-47

Clarke A (1992) Global warming, ocean cooling. Nature 360: $17-18$

Clarke RA, Gascard JC (1983) The formation of Labrador Sea Water. Part I: Large-scale processes. J phys Oceanogr 13: $1764-1778$

Clarke RA, Swift JH, Reid JL, Koltermann KP (1990) The formation of Greenland Sea Deep Water: double diffusion or deep convection? Deep Sea Res 37:1385-1424

Conover RJ (1988) Comparative life histories in the genera Calanus and Neocalanus in high latitudes of the northern hemisphere. In: Boxshall GA, Schminke HK (eds) Biology of copepods. Hydrobiologia 167/168:127-142

Cushing DH (1974) The natural regulation of fish populations. In: Harden Jones FR (ed) Sea fisheries research. Elek Science, London, p 399-412

Cushing DH (1988) The northerly wind. In: Rothschild BJ (ed) Toward a theory on biological-physical interactions in the world ocean. Kluwer Academic Publishers, Dordrecht, p 235-244

Cushing DH (1990) Plankton production and year-class strength in fish populations: an update of the match/mismatch hypothesis. Adv mar Biol 26:249-293

Dickson RR, Brander KM (1993) Effects of a changing windfield on cod stocks of the North Atlantic. Fish Oceanogr 2: 124-153

Dickson RR, Meincke J, Malmberg SAa, Lee AJ (1988) The 'Great Salinity Anomaly' in the northern North Atlantic 1968-1982. Prog Oceanogr 20:103-151

Ellertsen B, Fossum P, Solemdal P, Sundby S (1989) Relation between temperature and survival of eggs and first-feeding larvae of northeast arctic cod (Gadus morhua L.). Rapp P-v Réun Cons int Explor Mer 191:209-219

Ellertsen B, Solemdal P, Stromme T, Tilseth $S$, Westgaard $T$, Moksness E, Øiestad V (1980) Some biological aspects of cod larvae (Gadus morhua L.). FiskDir Skr (Ser Havunders) 17:29-47

Ellertsen $\mathrm{B}$, Solemdal $\mathrm{P}$, Sundby $\mathrm{S}$, Tilseth $\mathrm{S}$, Westgård $\mathrm{T}$, Øiestad V (1981) Feeding and vertical distribution of cod larvae in relation to availability of prey organisms. Rapp P-v Réun Cons int Explor Mer 178:317-319

Fitzpatrick C, Miller RJ (1979) Review of spawning times and locations for some commercial finfish on the Newfoundland and Labrador coasts. Fish Mar Ser tech Rep 905:1-14
Greatbatch R (1994) Interdecadal climate variability; a new perspective. CMOS Bull 22(1):14-15

Hakkinen S (1993) An arctic source for the Great Salinity Anomaly: a simulation of the arctic ice-ocean system for 1955-1975. J geophys Res 98(C9):16397-16410

Hassel A (1986) Seasonal changes in zooplankton composition in the Barents Sea, with special attention to Calanus spp. (Copepoda). J Plankton Res 8: 329-339

Helbig J, Mertz G, Pepin P (1992) Environmental influences on the recruitment of Newfoundland/Labrador cod. Fish Oceanogr 1:39-56

Hjort J (1914) Fluctuations in the great fisheries of northern Europe viewed in the light of biological research. Rapp P-v Réun Cons int Explor Mer 20:1-228

Hovgård H, Buch E (1990) Fluctuation in the cod biomass of the West Greenland Sea ecosystem in relation to climate. In: Sherman K, Alexander LM, Gold BD (eds) Large marine ecosystems - patterns, processes and yields. American Association for the Advancement of Science, Washington, DC, p 36-43

Hunt von Herbing I (1994) Form, function and energetics of the early life history of Atlantic cod (Gadus morhua). PhD thesis, Dalhousie University, Halifax

Huntley M, Strong KW, Dengler AT (1983) Dynamics and community structure of zooplankton in the Davis Strait and northern Labrador Sea. Arctic 36:143-161

Hutchings JA, Myers RA (1993) Effect of age on the seasonality of maturation and spawning of Atlantic cod, Gadus morhua, in the northwest Atlantic. Can J Fish Aquat Sci 50:2468-2474

Hutchings JA, Myers RA, Lilly GR (1993) Geographic variation in the spawning of Atlantic cod, Gadus morhua, in the northwest Atlantic. Can J Fish Aquat Sci 50:2457-2467

Ikeda M (1990) Decadal oscillations of the air-ice-ocean system in the Northern Hemisphere. Atmos-Ocean 28:106-139

Iles TD, Sinclair M (1982) Atlantic herring: stock discreteness and abundance. Science 215:627-633

Kane $J$ (1984) The feeding habits of co-occurring cod and haddock larvae from Georges Bank. Mar Ecol Prog Ser 16: $9-20$

Lazier JRN, Wright DG (1993). Annual velocity variations in the Labrador Current. J phys Oceanogr 23:659-678

Lear WH, Green JM (1984) Migration of the 'northern' Atlantic cod and the mechanisms involved. In: McCleave JD, Arnold GP, Dodson JJ, Neill WH (eds) Mechanisms of migration in fishes. Plenum Press, New York, p 309-315

Loeng $H$ (1991) Features of the physical oceanographic conditions of the Barents Sea. In: Sakshaug E, Hopkins CCE, $\varnothing$ ritsland NA (eds) Proceedings of the Pro Mare Symposium on polar marine ecology, Trøndheim, 12-16 May 1990. Polar Res 10(1):5-18

Maslanik JK, Barry RG (1989) Short-term interactions between atmospheric synoptic conditions and sea ice behaviour in the arctic. Ann Glaciol 12:113-117

Massom R (1991) Satellite remote sensing of polar regions: applications, limitations, and data availability. Lewis Publishers, Boca Raton

Melle W, Skjoldal HR (1989). Zooplankton reproduction in the Barents Sea: vertical distribution of eggs and nauplii of Calanus finmarchicus in relation to spring phytoplankton development. In: Ryland JS, Tyler PA (eds) Reproduction, genetics and distribution of marine organisms. Proc 23rd European Marine Biology Symposium. Olsen \& Olsen, Fredensborg, p 137-145

Mertz G, Myers RA (1994) The ecological impact of the Great Salinity Anomaly in the northern North-west Atlantic. Fish Oceanogr 3:1-14 
Mertz G, Narayanan S. Helbig J (1993) The freshwater transport of the Labrador Current. Atmos-Ocean 31:281-295

Mitchell JFB (1989) The 'greenhouse' effect and climate change. Rev Geophys 27:115-139

Myers RA, Akenhead SA, Drinkwater K (1990) The influence of Hudson Bay runoff and ice-melt on the salinity of the inner Newfoundland shelf. Atmos-Ocean 27:241-256

Myers RA, Cadigan NG (1993) Density-dependent juvenile mortality in marine demersal fish. Can J Fish Aquat Sci 50: $1576-1590$

Myers RA, Drinkwater KF (1988/1989) Offshelf Ekman transport and larval fish survival in the northwest Atlantic. Biol Oceanogr 6:45-64

Myers RA, Drinkwater KF, Barrowman NJ, Baird JW (1993b) Salinity and recruitment of Atlantic cod (Gadus morhua) in the Newfoundland region. Can J Fish Aquat Sci 50: $1599-1609$

Myers RA, Mertz G, Bishop CA (1993a) Cod spawning in relation to physical and biological cycles of the northern North-west Atlantic. Fish Oceanogr 2:154-165

Mysak LA, Manak DK (1989) Arctic sea-ice extent and anomalies, 1953-1984. Atmos-Ocean 27:376-405

Mysak LA. Manak DK, Marsden RF (1990) Sea-ice anomalies observed in the Greenland and Labrador Seas during 1901-1984 and their relation to an interdecadal arctic climate cycle. Clim Dyn 5:111-133

Mysak LA, Power SB (1991) Greenland Sea ice and salinity anomalies and interdecadal climate variability. Climatol Bull 25:81-91

Mysak LA, Power SB (1992) Sea-ice anomalies in the western Arctic and Greenland-Iceland Sea and their relation to an interdecadal cycle. Climatol Bull 26:147-176

Norrbin MF (1991) Gonad maturation as an indication of seasonal cycles for several species of small copepods in the Barents Sea. In: Sakshaug E, Hopkins CCE, Øritsland NA (eds) Proceedings of the Pro Mare Symposium on polar marine ecology. Trondheim, 12-16 May 1990. Polar Res 10(2):421-432

Page F, Frank KT (1989) Spawning time and egg stage duration in northwest Atlantic haddock (Melanogrammus aeglefinus) stocks with emphasis on Georges and Browns Bank. Can J Fish Aquat Sci 46 (Suppl.1):68-81

Peng S, Mysak LA (1992) A teleconnection study of interannual sea surface temperature fluctuations in the northern North Atlantic and precipitation and runoff over western Siberia. J Clim 6:876-885

Plourde S, Runge JA (1993) Reproduction of the planktonic copepod Calanus finmarchicus in the lower St. Lawrence Estuary: relation to the cycle of phytoplankton production and evidence for a Calanus pump. Mar Ecol Prog Ser 102: $217-227$

Pogson G, Mesa K, Boutilier RG (1993) Cod stocks in Maritime Canada: apples and pears. Ocean Prod Enhance- ment Network Channels 3(2):6-11

Prinsenberg SJ, Peterson IK (1994) Interannual variability in atmospheric and ice cover properties along Canada's east coast for 1962 to 1992. IAHR, Proc of the 12th International Symposium on Ice 1:372-381

Prinsenberg SJ, Peterson IK, Fowler GA (1993) Newfoundland shelf sea ice program, 1992. Can Tech Rep Hydrogr Ocean Sci 153:1-115

Read JF, Gould WJ (1992) Cooling and freshening of the subpolar North Atlantic Ocean since the 1960s. Nature $360: 55-57$

Rochet M, Grainger EH (1988) Community structure of zooplankton in eastern Hudson Bay. Can J Zool 66:1626-1630

Schmitz WJ Jr, McCartney MS (1993). On the North Atlantic circulation. Rev Geophys 31:29-49

Schott F, Visbeck M, Fischer J (1993) Observations of vertical currents and convection in the central Greenland Sea during the winter of 1988-1989. J geophys Res 98(C8) 14401-14421

Sinclair M (1988) Marine populations: an essay on population regulation and speciation. University of Washington Press, Seattle

Skreslet S (1989) Spatial match and mismatch between larvae of cod (Gadus morhua L.) and their principal prey, nauplii of Calanus finmarchicus (Gunnerus). Rapp P-v Réun Cons int Explor Mer 191:258-263

Smidt ELB (1989) Min Tid i Gronland, Grønland i mid Tid. Nyt Nordisk, Forlag Arnold Busck, Copenhagen

Smith WO Jr (1987) Phytoplankton dynamics in the marginal ice zone. Oceanogr mar Biol A Rev 25:11-38

Sutcliffe WH Jr, Loucks RH, Drinkwater KF, Coote AR (1983) Nutrient flux onto the Labrador Shelf from Hudson. Strait and its biological consequences. Can J Fish Aquat Sci 40 . $1692-1701$

Sverdrup HU (1953) On conditions for vernal blooming in phytoplankton. J Cons int Explor Mer 18:287-295

Tande KS (1991) Calanus in north Norwegian fjords and in the Barents Sea. In: Sakshaug E, Hopkins CCE, Øritsland NA (eds) Proc of the Pro Mare Symposium on polar marine ecology, Trøndheim, 12-16 May 1990. Polar Res 10(2): $389-407$

Tande KS, Hassel A, Slagstad D (1985) Gonad maturation and possible life cycle strategies in Calanus finmarchicus and Calanus glacialis in the northwestern part of the Barents Sea. In: Gray JS, Christiansen ME (eds) Marine biology of polar regions and effects of stress on marine organisms. John Wiley \& Sons, Chichester, p 141-155

Tourangeau S, Runge JA (1991) Reproduction of Calanus glacialis under ice in spring in southeastern Hudson Bay, Canada. Mar Biol 108:227-233

Van der Meeren T (1991) Algae as first food for cod larvae, Gadus morhua L.. filter feeding or ingestion by accident? J Fish Biol 39: 225-237 